University of Nebraska - Lincoln

DigitalCommons@University of Nebraska - Lincoln

Publications from USDA-ARS / UNL Faculty

U.S. Department of Agriculture: Agricultural

Research Service, Lincoln, Nebraska

2008

Corn Rootworm Areawide Pest Management in the Midwestern USA

Laurence D. Chandler

USDA-ARS-NPA

James R. Coppedge

USDA-ARS-NPA

C. Richard Edwards

Purdue University

Jon J. Tollefson

lowa State University

Gerald R. Wilde

Kansas State University

See next page for additional authors

Follow this and additional works at: https://digitalcommons.unl.edu/usdaarsfacpub

Part of the Agricultural Science Commons

Chandler, Laurence D.; Coppedge, James R.; Edwards, C. Richard; Tollefson, Jon J.; Wilde, Gerald R.; and Faust, Robert M., "Corn Rootworm Areawide Pest Management in the Midwestern USA" (2008).

Publications from USDA-ARS / UNL Faculty. 652.

https://digitalcommons.unl.edu/usdaarsfacpub/652

This Article is brought to you for free and open access by the U.S. Department of Agriculture: Agricultural Research Service, Lincoln, Nebraska at DigitalCommons@University of Nebraska - Lincoln. It has been accepted for inclusion in Publications from USDA-ARS / UNL Faculty by an authorized administrator of DigitalCommons@University of Nebraska - Lincoln. 


\section{Authors}

Laurence D. Chandler, James R. Coppedge, C. Richard Edwards, Jon J. Tollefson, Gerald R. Wilde, and Robert M. Faust 


\title{
Corn Rootworm Areawide Pest Management in the Midwestern USA
}

\author{
LAuREnCe D. Chandler, ${ }^{1}$ James R. Coppedge, ${ }^{2}$ \\ C. RICHARD EDWARDS, ${ }^{3}$ JON J. TOLLEFSON, ${ }^{4}$ \\ GERALD R. WILDE ${ }^{5}$ AND ROBERT M. FAUST ${ }^{6}$ \\ 1 USDA-ARS-NPA, Fort Collins, Colorado, USA \\ 2USDA-ARS-SPA, College Station, Texas, USA \\ ${ }^{3}$ Department of Entomology, Purdue University, West Lafayette, \\ Indiana, USA \\ ${ }^{4}$ Department of Entomology, lowa State University, Ames, lowa, USA \\ ${ }^{5}$ Department of Entomology, Kansas State University, Manhattan, \\ Kansas, USA \\ ${ }^{6}$ US Department of Agriculture, Agricultural Research Service, Beltsville, \\ Maryland, USA
}

\section{Introduction}

For many maize (Zea mays) producers across the Midwestern USA, as well as in parts of the northern and southern plains, the corn rootworm complex (Diabrotica spp;; Coleoptera: Chrysomelidae) has represented one of the greatest challenges to efficient, quality maize-grain production over the past $50-60$ years. Three species of corn rootworm are particularly troublesome: the western corn rootworm, Diabrotica virgifera virgifera, the northern corn rootworm, $D$. barberi and the Mexican corn rootworm, $D$. virgifera zeae, all have consistently been important economic pests of maize (Metcalf, 1986b). Prior to the introduction of transgenic maize varieties designed for corn rootworm management, from 8-10 million ha were treated with soil-applied insecticides to protect maize roots from larval feeding, with no absolute guarantee that the plants would be protected.

Corn rootworms damage maize primarily through larvae feeding on the roots. Severe feeding can result in lodged or stunted plants due to substantial root loss (Chandler, 2003). Over the years prior to the mid-1990s yield losses varied annually, but when the value of those losses was combined with the cost of control, these averaged at around US $\$ 1$ billion per year (Chandler et al., 1998). Adult corn rootworms can also inflict damage to maize plants through feeding on silk and pollen. Large numbers of rootworms feeding on silk can substantially reduce pollination, which interferes with kernel set and reduces yield.

This article is a U.S. government work, and is not subject to copyright in the United States. 
During the late 1980s and 1990s several changes occurred related to corn rootworm biology and ecology, which increased the difficulty of managing this pest. Soil insecticides, which had been used extensively to manage corn rootworm larvae (Chandler et al., 2000), came under increased scrutiny for their perceived negative environmental impact. Although there are probably no published data supporting and/or refuting the environmental effects of insecticides applied directly for rootworm control, public concern over the practice helped focus the need for development of alternative control methods to manage this insect complex. The single most important concern related to insecticide application to the soil was the known fact that many insecticides were used without knowledge of need - e.g. did the number of potential larvae within a maize field warrant the use of the insecticide to protect the crop? (Sutter et al., 1991; Gray et al., 1992). Additionally, soil insecticides did not always reduce corn rootworm populations and thus did not serve as reliable management tools for reducing pest densities that would attack maize roots in subsequent growing seasons.

To determine the need for insecticide applications it is best to base the decision on an insect-sampling regime that targets a critical stage of an insect's life cycle. For corn rootworms, sampling the immature stages could provide the best information on the need to intervene to protect maize roots. However, sampling for eggs and larvae of this insect complex is difficult, expensive and, perhaps, unreliable. In many instances it was just simpler, as well as more economical, for growers to apply an insecticide without knowledge of pest density. Prophylactic insecticide application served as a simple insurance policy that was generally cheap and reliable.

In addition to soil insecticides, foliar insecticides have been used to reduce adult corn rootworm populations, in theory limiting the number of females laying eggs that would potentially hatch the following year. However, in the 1960s, western corn rootworm beetle populations developed resistance to foliar applied insecticides in the chlorinated hydrocarbon class (Ball and Weekman, 1962), and later to foliar-applied carbamates and organophosphates in Nebraska during the mid-1990s (Meinke et al., 1998). In parts of Nebraska significant levels of resistance to microencapsulated methyl-parathion and carbaryl, two widely used foliar insecticides, were detected (Meinke et al., 1998; Siegfried et al., 1998; Wright et al., 2000). Although most instances of resistance to these compounds have been reported in adult populations, evidence also suggests that larvae of these same resistant adult populations may be somewhat tolerant to certain soil insecticides (Wright et al., 2000).

Resistance to the chlorinated hydrocarbons in the 1960s forced many growers to start alternating maize with other crops on an annual basis. Corn rootworm larvae do not travel great distances to seek maize roots (Short and Luedtke, 1970), and they cannot feed and survive on roots of numerous alternative crop species commonly grown in many Midwestern production areas (e.g. soybean, lucerne, wheat, etc.). By rotating crops it was assumed that one could significantly disrupt the corn rootworm life cycle and thus reduce the insecticide use needed to manage rootworm populations and minimize damage in maize.

Insects do tend to adapt to perturbations forced upon their populations. Although rotating crops appeared to work effectively for many years, during the 1980s numerous populations of northern corn rootworms in parts of the Midwest developed an extended diapause in response to the selection pressure applied by annual crop rotation of large areas of crop land. This biological phenomenon of 
extended diapause allowed the insects to survive as eggs in the soil for more than one growing season (Krysan et al., 1986). Thus, rotation of crops did not completely solve northern corn rootworm management, nor did it reduce the insecticide use problems.

More recently, as a response to crop rotation during the $1990 \mathrm{~s}$, western corn rootworms in Illinois/Indiana began to oviposit in soybean (Glycine max) (Edwards et al., 1996). When these eggs hatched the following season, where maize had been planted after the soybeans, the maize suffered substantial economic damage. This phenomenon has spread to several surrounding states (e.g. Ohio, Michigan and perhaps Iowa) and has created numerous dilemmas for maize production specialists. A similar phenomenon was observed with Mexican corn rootworms laying eggs in grain sorghum (Sorghum bicolor) in Texas during the 1990s (J. R. Coppedge, personal communication). This probably occurred as a direct response to annual rotation between maize and grain sorghum.

As management of the corn rootworm complex became more challenging in the 1980 s to mid-1990s, it was apparent that alternative control tactics were needed to effectively limit larval feeding damage to maize roots and to provide an economical alternative to the traditional soil and/or foliar insecticides. Thus, during this critical timespan, scientists at USDA-ARS and cooperating land grant universities initiated research to identify new management tools to effectively combat the economic threat posed by this insect complex (Chandler, 2003). The remainder of this chapter will discuss development and evaluation of a novel insect behavioural-based technology, designed to manage corn rootworm adult populations and limit oviposition, thus reducing the number of larvae available to feed on and damage maize roots early in the growing season. We will also discuss implications for use of such a technology in areawide pest management (AWPM).

\section{Technology Development}

Beginning in the 1980 s and continuing into the early to mid-1990s, collaborating scientists began to address development of a new corn rootworm management technology that took advantage of the corn rootworm beetle's natural attraction to plants in the family Cucurbitaceae. Many early biological/ecological studies had previously identified the strong attraction of beetles to various compounds, including flowers, from plants in the melon family. Several plant- and flower-produced chemicals, or their analogues, were identified that attracted beetles and/or served as feeding stimulants (Metcalf et al., 1982, 1987; Ladd et al., 1983; Metcalf, 1986a; Lampman and Metcalf, 1987; Lampman et al., 1987; Metcalf and Lampman, 1989; Lance and Elliott, 1991; Sutter and Lance, 1991). These compounds appeared to mimic the odours of floral structures and attracted both insect sexes.

Conceptually, use of these compounds in a novel formulation designed to attract beetles to a single point and to stimulate their willingness to feed on a bait containing a low dose of a highly toxic insecticide seemed to hold promise as an environmentally friendly management tool (Chandler, 2003). With this foundation, scientists worked for approximately 4-5 years (ending in the early 1990s) to develop a semiochemical insecticide bait that would prove to be effective in killing a high percentage of beetles 
in maize fields where it was applied (Lance, 1988; Lance and Sutter, 1991, 1992, 1993; Sutter and Lance, 1991; Weissling and Meinke, 1991a, b; Sutter and Hesler, 1993; Sutter et al., 1998).

The bait was composed of natural cucurbitacins, a common insecticide used as a toxicant, and a non-toxic, edible carrier. Cucurbitacins are bitter-tasting tetracyclic triterpenoids that stimulate feeding in rootworm adults and repel non-rootworm insects. Cucurbitacins are found in most plants within the Cucurbitaceae, and were found in high concentrations in roots of the wild buffalo gourd, Cucurbita foetidissima, as well as in fruit of several melon species (Chandler, 2003). Meinke (1995) provided evidence of potential benefits from this behaviour-based approach. These included: (i) effective beetle control obtainable with small amounts of insecticide per hectare; (ii) few adverse effects on non-target organisms because the baits must be ingested; and (iii) human exposure to insecticides and potential environmental contamination were reduced because of the small amount of toxin in the bait.

During the initial research and development stage, scientists evaluated numerous bait compounds. After several experimental trials, two compounds, SLAM ${ }^{\circledR}$ (Microflo Co. and BASF Corp.) and Compel ${ }^{\circledR}$ (Ecogen, Inc.), were chosen to be more fully tested in large-scale field trials (Sutter et al., 1998). These baits were composed of dried, powdered root of the buffalo gourd, carbaryl and a carrier. SLAM ${ }^{\circledR}$ was produced as a microsphere and included minute amounts of carbaryl as the toxicant. The microsphere breaks down into a suspension in water and can easily be sprayed (Chandler, 1998). Compel ${ }^{\circledR}$ was developed as a flowable compound where all ingredients, including carbaryl, were combined with a sticky carrier prior to being flung out from a spinning cone attached to the wing of an aircraft. Both baits adhere to plant surfaces and stimulate rootworm adult feeding, which exposes the insect to efficacious levels of toxicant (Chandler et al., 2000). Both compounds were found to be highly efficacious against corn rootworm beetles, using about 95-98\% less insecticide per ha than traditional foliar applications of carbaryl.

Following extensive testing, SLAM ${ }^{\circledR}$ proved easier to use and thus was selected as a preferred product for additional evaluation and possible use in AWPM programmes (Sutter et al., 1998). Numerous field applications to rootworm-infested maize were made with SLAM ${ }^{\circledR}$, with most studies clearly showing that the bait was effective and highly efficacious against the adults, could reduce adult corn rootworm abundance during the critical oviposition period and could easily be applied via conventional aerial or ground applicators (Hoffmann et al., 1996a, b, 1998; Chandler and Sutter, 1997; Chandler, 1998). Additionally, SLAM ${ }^{\circledR}$ was found generally to have no significant negative impact on beneficial arthropods (Ellsbury et al., 1996a, b; Chandler and Sutter, 1997; Hoffmann et al., 2000). Thus the bait appeared to be both effective in reducing corn rootworm beetle populations and environmentally friendly.

Additional bait products were developed in the mid- to late 1990s as part of the natural evolution of the existing products, the discovery of other important sources of high concentrations of cucurbitacin and numerous user concerns over the manufacturing and quality control of SLAM ${ }^{\circledR}$. These concerns eventually led to the withdrawal of SLAM ${ }^{\circledR}$ as a commercially available product in 1998/1999. These new products included Invite ${ }^{\circledR}$ (Florida Food Products, Inc.) and CideTrak ${ }^{\circledR}$ CRW (Trece, Inc.). Unlike SLAM ${ }^{\circledR}$, both Invite ${ }^{\circledR}$ and CideTrak ${ }^{\circledR}$ CRW were not formulated with insecticide during manufacturing (Chandler, 2003). Similar to Compel ${ }^{\circledR}$, 
insecticides of choice were added to these compounds at the time of mixing for application. Both new products were efficacious against corn rootworm beetles and demonstrated to be viable alternatives to SLAM ${ }^{\circledR}$.

As with any insecticide-based insect management tool, timing of application of a toxicant is critical to its effectiveness. In theory, semiochemical baits are applied to maize plants when adult corn rootworms are most abundant and preferably at or before the females start to oviposit. Beetle numbers and life stage identification are important factors needed to time an application.

To determine effectively the number of corn rootworm beetles in a field, several techniques were evaluated in conjunction with bait applications. For optimal and economical decisions to support bait applications, the unbaited Pherocon ${ }^{\circledR}$ AM (yellow sticky) trap manufactured by Trece, Inc. was found to be the best for monitoring beetle populations. It compared favourably to traditional visual counts of the number of adults per maize plant (Chandler, 2003). A cumulative catch of four to seven beetles per trap per day over 7 consecutive days, when gravid females were present, was determined to be an effective threshold to initiate bait applications in maize. Placement of adequate numbers of traps in maize fields, beginning at the time of adult emergence from the pupal stage, allows pest management specialists effectively to time bait applications. Monitoring subsequent adult populations must continue for 6 weeks to determine whether additional applications are needed. Economics of trapping (trap costs and labour involved in placing and collecting traps) is the limiting factor for widespread adoption of yellow sticky traps as monitoring tools.

\section{Formal AWPM Programme Implementation}

As development of the semiochemical insecticide baits continued in the early 1990s the USDA-ARS initiated an Areawide Pest Management Program (APMP) in response to the USDA Pest Management (IPM) Initiative (USDA, 1993, 1994). The goal of this initiative was to implement IPM over at least $75 \%$ of the US crop acreage by 2000. In 1993, ARS, various university research and extension personnel and personnel from several state Departments of Agriculture met in Washington, DC to identify key pests and cropping systems for which environmentally sound pest management technologies were available for implementation on an areawide basis (Faust and Chandler, 1998). One of the projects selected was the management of adult corn rootworms within the maize pest management system in the Midwest using a semiochemical insecticide bait.

In 1995, the USDA-ARS-sponsored corn rootworm AWPM programme was initiated. An ad hoc committee comprising individuals from ARS, USDA-CSREES, USDA-ERS and the Extension Service was formed to guide the development and implementation of the programme. The committee organized a stakeholder meeting in St Louis, Missouri during this initial year to gather input from interested parties and to determine the feasibility of implementation. After this meeting several additional meetings were held to seek further input and to develop a team of research and extension personnel who would roll out the programme across the US maize belt. 
From these meetings a conceptual plan was developed and the programme fully implemented in the spring of 1997 (Chandler, 2003).

The programme was divided into four distinct phases: (i) site development and information gathering - 1996; (ii) implementation - 1997; (iii) programme continuation, 1998-2001; and (iv) final assessment and technology transfer - 2002 (Chandler et al., 2000). The mission of the programme was the successful establishment and implementation of an areawide demonstration programme that: (i) is the result of a partnership of growers, private consultants, applicators and suppliers, research and extension personnel and local, state and federal agencies who have a stake in the development and adoption of improved crop management technologies; and (ii) clearly demonstrates the advantages of enhanced grower profits, reduced risks, enhanced environmental compatibility and superiority of IPM approaches compared with current pest control approaches (Chandler et al., 2000).

The established goals of the programme were to: (i) demonstrate an AWPM concept for the control of corn rootworm and other pests of maize such that voluntary adoption would occur throughout all maize production regions; and (ii) develop a partnership of federal, state, local and private interests that would be involved in the programme from conception to adoption (Chandler et al., 2000).

ARS provided approximately US $\$ 550,000$ for Phase I funding in fiscal year 1996, with approximately US $\$ 1.6$ million provided annually from 1997 to 2001 . Funds were distributed to cooperators using established ARS intra-agency fund transfers and specific cooperative agreements with cooperating universities. At the time of programme initiation, the potential advantages of conducting an AWPM programme for corn rootworm included: (i) consistency of control using standardized management strategies across a wide geographic area; (ii) reduced insect pest movement among fields; (iii) cost effectiveness compared with a field-by-field management approach; and (iv) reduced pest populations within a defined area (USDA-ARS/IDEA, 2004).

\section{Site Selection and Programme Execution}

Five corn rootworm AWPM sites, with associated non-areawide-treated control fields, were identified for use in the programme (Chandler et al., 2000; Chandler, 2003). Each site was selected for its uniqueness and ability to adequately reflect various growing conditions and corn rootworm challenges faced across the US maize production areas. Five sites were selected:

Site A, the Illinois/Indiana site located in eastern Iroquois County, Illinois and western Benton County and Newton County, Indiana was approximately $41 \mathrm{~km}^{2}$ in size with a total of 45 cooperating growers and approximately 4600 ha of maize and soybean in more than 160 fields. This site was within the heart of the region experiencing significant western corn rootworm behavioural changes resulting in oviposition in soybean. The faculty from Purdue University managed the site, with assistance from colleagues at the University of Illinois.

Site B, the Iowa site located in Clinton County, Iowa was approximately $41 \mathrm{~km}^{2}$ in size, with a total of 40 cooperating growers and more than 2500 ha of maize in over 100 fields. This site targeted both northern and western corn rootworm in 
a primarily continuous maize production area. Some soybean was grown in rotation along with pasture crops. The faculty from Iowa State University managed the site.

Site C, the Kansas site located in Republic County, Kansas was approximately $41 \mathrm{~km}^{2}$ in size, with 36 cooperating growers and more than 1700 ha of maize in over 90 fields. This site targeted western corn rootworm in a furrow-irrigated, continuous maize production area. The faculty from Kansas State University managed the site.

Site D, the Texas site located in Bell County, Texas was approximately $21 \mathrm{~km}^{2}$ in size, with eight cooperating growers and approximately 800 ha of maize and 300 ha of grain sorghum. This site targeted Mexican corn rootworm in a primarily dryland maize/grain sorghum production system and was initiated a year earlier (in 1996) than the other sites. The site was managed by ARS personnel from College Station, Texas, in cooperation with the faculty from the Texas Agricultural Extension Service and Texas A\&M University.

Site E, the South Dakota site located in Brookings County, South Dakota. The site was approximately $41 \mathrm{~km}^{2}$ in size, with 20 cooperating growers and approximately 1400 ha of maize in over 50 fields. The site targeted northern and western corn rootworm in a primary maize/soybean rotation area. Some continuous maize was grown under centre-pivot irrigation systems. The site was managed by ARS personnel from Brookings, South Dakota in cooperation with the faculty from South Dakota State University.

\section{Corn rootworm monitoring}

Each AWPM site team was charged with monitoring corn rootworm beetle populations using traditional sampling methodologies (Chandler, 2003). Pherocon ${ }^{\circledR}$ AM (yellow sticky) traps were selected as the primary tool for monitoring beetle populations in maize and for initiating semiochemical insecticide-bait applications in maize at Sites $B, C$ and $\mathbf{E}$. Pherocon ${ }^{\circledR}$ AM traps were also used to monitor beetles and initiate bait applications to soybean in Site A. A minimum of six yellow sticky traps equally distributed throughout a field, regardless of size, were required for monitoring (Chandler et al., 1999). Trapping began as soon as adults began to emerge and continued through a large portion of the remaining growing season. Hein and Tollefson (1985) had previously reported on the effectiveness of Pherocon ${ }^{\circledR}$ AM traps as a scouting tool for predicting damage by larvae the following year based on beetle counts the previous year.

Adult counts from maize plants were used to trigger bait applications to maize at Sites A and D. A cumulative count of from four to seven beetles per yellow sticky trap per day over 7 consecutive days - when gravid female rootworms were present - was used as the threshold to apply bait in maize. Bait applications in soybean were made when two beetles per trap per day over 7 days had been captured. Maize plant counts triggered bait applications when counts of 0.5 beetles per plant or more were observed and when gravid females were present. Baits were reapplied as necessary if corn rootworm populations returned to the above treatment thresholds (Chandler et al., 2000). 


\section{Baits and applications}

SLAM ${ }^{\circledR}$ was the original bait of choice for the programme. Each site used SLAM ${ }^{\circledR}$ exclusively from 1997 to 1999 and parts of 2000 . At that time, SLAM ${ }^{\circledR}$ was no longer manufactured and each site had a choice of using Invite ${ }^{\circledR}$ or CideTrak ${ }^{\circledR}$ CRW combined with carbaryl through the remainder of the programme. Applications of bait were made using aircraft at all sites and following methodology described by Hoffmann et al. (1996a, b). Baits were applied in $3.785 \mathrm{l}$ of water/ha at rates ranging from 53-106 $\mathrm{g}$ of carbaryl/ha.

\section{Effectiveness assessment}

In addition to the trap and whole plant counts conducted before and following each bait application, maize root damage ratings using the Iowa 1-6 scale (Hills and Peters, 1971) were conducted in each year to determine the effectiveness of the programme in protecting maize roots (Chandler, 2003). Higher root ratings indicated greater feeding damage, with ratings of three or over considered economic. Root injury was also assessed in control fields outwith the management areas where growers had applied insecticides to the soil at planting for larval control and left an area that had not been treated with an insecticide. These comparisons contrasted with the AWPM approach of controls applied by individual farmers. Additionally, some sites used beetle-emergence cages ( $1 \mathrm{~m}^{2}$ in size) in the management area and control fields to assist in monitoring the sex ratios of the corn rootworm population and in determining the success of baits in reducing rootworm densities in maize fields 1 year after treatment compared with conventional practices.

\section{Supporting Research}

In addition to the bait application and population monitoring portion of the programme, four additional supporting research activities were conducted to assist in final assessment of the AWPM approach:

\section{Insecticide resistance management}

Entomologists at the University of Nebraska, in cooperation with ARS personnel in Brookings, South Dakota, monitored corn rootworm adult susceptibility to carbaryl, related insecticides and cucurbitacin at all areawide sites throughout the duration of the programme. Associated studies were conducted to determine factors responsible for development of carbaryl and methyl parathion resistance in various western corn rootworm populations, as well as to determine the biochemical and molecular mechanisms involved in resistance (Ghandler, 2003). 


\section{Economic assessment}

Agricultural economists at Purdue University collected data and provided vital information for producers on the economic impact of the programme related to farm profits. The data determined the type of maize production system most likely to benefit from an AWPM approach (Chandler, 2003).

\section{Sociological assessment}

Rural sociologists from Iowa State University conducted on-site surveys and assessments to determine barriers and opportunities for successful implementation of the programme. Business models were identified that could be used to transfer the technology and sustain it within the private sector (Chandler, 2003).

\section{Non-target arthropod assessment}

Entomologists from South Dakota State University, in cooperation with ARS personnel in Brookings, South Dakota and faculty/staff of Iowa State University, conducted population density assessments of non-target arthropods following SLAM ${ }^{\circledR}$ applications in sites $\mathbf{B}$ and $\mathbf{E}$.

\section{Results and Conclusions}

As with any large-scale IPM programme, the results of the corn rootworm AWPM programme varied greatly from site to site. The measures of success with a programme of this type should be viewed not only in the ability to manage a difficult insect pest, but also in the amount of new knowledge generated from the actions of a large and diverse team of scientists, stakeholders and end-users. Listed below are summary findings from each of the five management sites:

Site A: the site root ratings conducted in 2001 showed a significant reduction in corn rootworm larval feeding damage within the areawide site compared with fields in the companion control area. Ratings averaged 1.73 and 3.26 (Iowa 1-6 root rating scale) in the management site and control area, respectively. The difference in root ratings indicated that areawide suppression had had an effect on rootworm populations in this particular year, but similar results were not seen in other years. Substantial problems occurred related to efficacy of the semiochemical baits, which resulted in an increased number of applications in each year. Questions on whether this approach is economical in this area still exist (C.R. Edwards, 2001, personal communication; Chandler, 2003; Gerber, 2004).

Site B: over the life of the programme, western corn rootworm larval feeding damage within the management site was less than that observed in control areas where no soil insecticides had been applied. Root ratings averaged 2.2, 2.6, 1.4 and 1.9 (Iowa 1-6 root rating scale) in 1998, 1999, 2000 and 2001, respectively, in the 
AWPM site compared with 3.5, 3.6, 2.5 and 2.0 during the same years in the control fields. During the same period corn rootworm beetles produced in the managed area averaged $232,000,447,000,235,000$ and 514,000/ha, respectively, compared with $909,000,1,161,000,420,000$ and 1,773,000/ha in the control fields (Tollefson, 1998;J.J. 'Tollefson, 2001, personal communication; Chandler, 2003).

Despite the substantial reduction in beetle numbers, there are still questions as to whether the remaining numbers pose an economic threat to maize producers in the following year. In general, the number of bait applications needed to manage the pest remained stable in each year. If $80 \%$ of the 12,693 ha of maize protected by the adult corn rootworm management programme over 5 years had received the commonly used $229 \mathrm{~g}$ of organophosphorus insecticide/ha, 10,154 ha would have been treated with $232,527 \mathrm{~g}$ of active ingredient. This represents $14,226,850 \mathrm{~g}$ of actual toxicant rather than the $665,417 \mathrm{~g}$ of carbaryl that were applied to the Iowa managed area during the study, more than a 20 -fold reduction in insecticide load in the environment.

Site C: following implementation of the programme in 1998, the percentage of maize hectarage above treatment thresholds requiring bait applications within the management site had been reduced from 51 to $15 \%$ by 2001 . The percentage of hectarage above treatment thresholds in the control (unmanaged) areas ranged from 74.5 to 87.5 over the same period. An average of only $33.5 \%$ of maize fields in the managed area exceeded economic beetle populations over the programme compared with $82.8 \%$ in the control (unmanaged) fields (Wilde et al., 1998; G.E. Wilde, 2001, personal communication; Chandler, 2003; USDA-ARS/IDEA, 2004). It appears that a continuous maize production system in irrigated portions of the western Midwest is the most likely target for successful implementation of the AWPM concept against western corn rootworms.

Site D: large numbers of Mexican corn rootworms surviving in grain sorghum, as well as in maize, resulted in a substantial challenge for consistent areawide management results. However, over the life of the programme, the percentage of maize hectarage requiring bait applications to manage the insect was reduced from 90 to 18\%. These results would indicate that the programme was successful (Lingren, 1999; J.R. Coppedge, 2001, personal communication; USDA-ARS/IDEA, 2004). However, the main challenge to maintaining a successful programme in typical Texas maize production areas is related to the economics of dryland agriculture. Droughts reduce yields and thus growers are reluctant to maintain intensive pest management programmes, which cut into their profit margins.

Site E: large numbers of northern corn rootworms within the management site rendered the use of semiochemical baits extremely challenging. This particular species of rootworm does not respond as well to the feeding stimulants/attractants within the baits, unlike western corn rootworms. Thus the management site did not see true reductions in the number of necessary bait applications from the start until the termination of the programme. The baits were as effective as traditional soil insecticides in maintaining reduced amounts of larval root feeding, but the difficulties encountered in managing northern corn rootworm make this particular maize production area a challenge for areawide implementation (L.D. Chandler, 2001, personal communication; USDA-ARS/IDEA, 2004).

Despite the numerous challenges encountered in implementing an AWPM programme against the corn rootworm complex, this programme resulted in substantial 
positive findings that will have some impact on corn rootworm management for many years to come. The use of baits, although overall no more successful in reducing root feeding damage than soil insecticides, did significantly reduce the total amount of insecticide applied to the areawide management sites. As previously mentioned, in the entire Iowa site, the bait application programme reduced the total amount of insecticide active ingredient used by as much as 20-fold compared with conventional soil insecticides, if all hectares were treated as required. Similar results were achieved in all sites by the entire AWPM programme (USDA-ARS/IDEA, 2004). The environmental savings achieved because of the programme have positive consequences for the entire USA.

In addition to the above environmental benefits, several other products were developed during the life of the programme that benefit producers (USDA-ARS/ IDEA, 2004):

- Refined aerial bait application methods: aerial application protocols developed by scientists in the programme are now consistently used to optimize bait effectiveness.

- New traps: traps were developed by scientists in cooperation with Trece, Inc., to monitor corn rootworm beetle emergence and to trigger bait applications; the traps are now commercially available.

- Biological model: a new model was developed by scientists at Iowa State University that allows beetle emergence from the soil to be predicted with more precision; growers now need only monitor maize fields during a 4-week period of the growing season rather than the 8-10 weeks previously required (Nowatzki et al., 2002; Park and Tollefson, 2006).

- Rapid identification of rootworm insecticide resistance; University of Nebraska and ARS researchers developed a vial bioassay technique that more quickly and easily assesses the insecticide resistance status of field-collected western corn rootworms. This tool can be used to make informed selections of insecticides when treatments are required.

- Pherocon ${ }^{\circledR} \mathrm{AM}$ (yellow sticky) traps were used to develop economic injury level (EIL) and economic thresholds (ET) for western corn rootworm captures in soybean in Indiana and Illinois. The EIL was set at seven beetles captured per trap per day and the ET was determined to be five beetles captured per trap per day (Gerber, 2004).

- Two new insecticide baits were developed, CideTrak CRW ${ }^{\circledR}$ and Invite ${ }^{\circledR}$, which remain available from Trece, Inc. and Florida Food Products, Inc, respectively (Chandler, 2003). Pingel et al. (2001) assisted this effort by evaluating techniques to improve residual activity of the baits, and Schroder et al. $(1998,2001)$ assisted in development of new cucurbitacin sources resulting in development of Invite ${ }^{\circledR}$. These baits provided growers with the additional freedom of selecting and using an insecticide of their choice within the mixtures.

As the programme progressed, much was learned about the economic and sociological benefits of conducting an AWPM programme across maize production areas of the USA. Studies conducted by Purdue University economists indicated that the Kansas areawide site showed the greatest potential to benefit economically from the adoption of AWPM of rootworms. This conclusion was based on a study of net 
present value analyses over an 8-year planning horizon (Quan, 1999). Kansas growers can more readily afford the costs of scouting and bait applications, and results of the analyses indicated they would see an increase in their on-farm income.

Sociologists at Iowa State University developed three business models that could continue to sustain a corn rootworm AWPM programme after scientists and other interested parties have stopped the research and demonstration component of the programme (Padgitt, personal communication, 2004; USDA-ARS/IDEA, 2004):

- Private supplier model - private business management as a service to individual growers, at an economic advantage compared to traditional costs (preferred by participants in the corn rootworm AWPM programme).

- Collective enterprise model - growers organized as a cooperative/non-profit enterprise to provide AWPM.

- Special-use model - special tax revenues are collected from a geographical area or district designated by an authoritative body to cover the costs of AWPM.

At the end of the programme, many questions remained concerning the viability of the AWPM concept for corn rootworm. The onset and subsequent expanded use of genetically modified maize varieties targeted at corn rootworm has reduced the concerns over traditional corn rootworm management techniques (soil insecticides, foliar insecticides and crop rotations), and has thus negatively affected the probability of using AWPM techniques across the maize belt. Currently variations of AWPM for corn rootworm continue to be used in portions of western Kansas and in selected pockets in southern and central Texas. Additionally, it is apparent that AWPM-supported activities have achieved several scientific successes during the life of the USDAARS-sponsored programme. Some important conclusions and/or findings from the programme include:

- Combining several techniques such as baits, genetically modified maize varieties, insecticides and efficient crop scouting techniques is crucial for achieving true IPM success and minimizing insecticide resistance development in adult corn rootworms.

- Carbaryl susceptibility of western corn rootworm populations was reduced in areas with repeated SLAM ${ }^{\circledR}$ applications over a 4-year period (Zhu et al., 2001).

- The efficacy of feeding stimulants or baits, such as Invite ${ }^{\circledR}$, in combination with certain insecticides may be compromised by previously identified resistance and by insecticides that antagonize the feeding stimulation of the cucurbitacin bait, with both inoxacarb and fipronil providing effective alternatives to carbaryl within the bait (Parimi et al., 2003).

- Use of semiochemical-based baits did not significantly affect population densities of non-target arthropods when used as prescribed in an area management programme (Boetel et al., 2005).

- AWPM of adult beetles may result in fewer fields to scout and reduced insecticide use - lowering both economical and environmental costs/concerns.

- Crop rotation remains an economically viable control strategy unless the area has a high number of western corn rootworm beetles laying eggs in both maize and soybean, or a high number of northern corn rootworms exhibiting extended diapause traits. 
- Successful adoption of AWPM strategies will require innovative marketing and the willingness of growers to work together for a common goal. Making growers aware of the potential advantages of AWPM, increasing the use of IPM techniques and providing opportunities for enterprising agribusiness suppliers will encourage adoption of new and unique rootworm management options.

\section{Acknowledgements}

The authors would like to express their sincere appreciation to the numerous individuals who have worked on and supported the corn rootworm AWPM concept since the early 1990s. In particular, we would like to acknowledge the following individuals (in alphabetical order) for their contributions to various aspects of the programme: Mr Mike Athanas, Mr Dave Beck, Ms Amber Beckler, Dr Robert Behle, Dr Ed Berry (retired), Mr Larry Bledsoe, Dr Mark Boetel, Dr Wayne Buhler, Dr Larry Buschman, Dr Jesse Cocke (retired), Dr Stan Daberkow, Dr Mike Ellsbury, Dr Wade French, Dr Billy Fuller, Dr Corey Gerber, Dr Mike Gray, Dr Leslie Hammack (retired), Ms Anetra Harbor, Ms Deb Hartman, Dr Randy Higgins (deceased), Dr Clint Hoffmann, Ms. Denise Hovland, Mr Aaron Howell, Dr Gretchen Jones, Mr Nimesh Kadakia, Dr Buddy Kirk (retired), Dr Dave Lance, Dr Les Lewis, Dr Scott Lingren, Dr Marshall Martin, Dr Michael McGuire, Ms. Sarah McKenzie, Dr Lance Meinke, Mr Tara Mishra, Dr Tim Nowatzki, Mr Mike O’Neil, Dr Eldon Ortman (retired), Dr Steve Padgitt, Dr Srinivas Parimi, Dr Yung Lak Park, Dr Peggy Petrzelka, Dr Randy Pingel, Mr Peter Quan, Dr Walt Riedell, Dr Mike Scharf, Dr Robert Schroder (retired), Dr Roxanne Shufran, Dr Blair Siegfried, Dr Phil Sloderbeck, Ms Christina Welch Stair, Dr Jenny Stebbing, Dr Kevin Steffey, Dr Gerald Sutter (retired), Dr Jeff Whitworth, Dr Bob Wright, Dr X. Zhou and Dr K.Y. Zhu.

Additionally, the programme members thank members of Private Industry representing BASF Corp., MicroFlo Co., Ecogen, Inc., Trece, Inc. and Florida Foods International for their valuable assistance. Finally, the programme would not have been possible without the assistance of the more than 150 farmers and consultants who participated by allowing access to their farms for conduct of the studies.

\section{References}

Ball, H.J. and Weekman, G.T. (1962) Insecticide resistance in the adult western corn rootworm in Nebraska. Foumal of Economic Entomology 55, 439-441.

Boetel, M.A., Fuller, B.W., Chandler, L.D., Tollefson, J.J., McManus, B.L., Kadakia, N.D. and Mishra, T.A. (2005) Nontarget arthropod abundance in areawide-managed corn habitats treated with semiochemical-based bait insecticide for corn rootworm (Coleoptera: Chrysomelidae) control. Journal of Economic Entomology 98, 1957-1968.

Chandler, L.D. (1998) Comparison of insecticide-bait aerial application methods for management of corn rootworm (Coleoptera: Chrysomelidae). Southwestern Entomologist 23, 147-159. 
Chandler, L.D. (2003) Corn rootworm areawide management program: United States Department of Agriculture-Agricultural Research Service. Pest Management Science 59, 605-608.

Chandler, L.D. and Sutter, G.R. (1997) High clearance sprayer methods for application of corn rootworm (Coleoptera: Chrysomelidae) semiochemical-based baits. Southwestem Entomologist 22, 167-178.

Chandler, L.D., Woodson, W.D. and Ellsbury, M.M. (1998) Corn rootworm IPM: implementation and information management with GIS. In: Wilkinson, D. (ed.) Proceedings of the American Seed Trade Association 52nd Annual Com and Saybean Research Conference, Chicago, Illinois, pp. 129-143.

Chandler, L.D., Ellsbury, M.M. and Woodson, W.D. (1999) Area-wide Management Zones for Insects. PPI Site-specific management guidelines, SSMG-19, 4 pp.

Chandler, L.D., Coppedge, J.R., Edwards, C.R., Tollefson, J.J. and Wilde, G.E. (2000) Corn rootworm area-wide management across the United States. In: Tan, K.H. (ed.) Area-Wide Control of Fruit Flies and Other Insect Pests. Penerbit Universiti Sains Malaysia, Penang, Malaysia, pp. 159-168.

Edwards, C.R., Bledsoe, L.W. and Obermyer, J.L. (1996) The dramatic shift of the western corn rootworm, Diabrotica virgifera virgifera LeConte (Coleoptera: Ghrysomelidae), to maize in rotation with soybeans in Indiana. In: Anon. (ed.) Proceedings of the XX International Congress of Entomology, Florence, Italy, paper \#15- 082, pp. 469.

Ellsbury, M.M., Gaggero, J.M. and Johnson, T.B. (1996a) Mortality of lady beetle adults and lacewing larvae following exposure to semiochemical-based corn rootworm baits. Arthropod Management Tests 21, 402-403.

Ellsbury, M.M., Gaggero, J.M. and Johnson, T.B. (1996b) Survival of ground beetles (Carabidae) after feeding on western corn rootworm adults killed by semiochemicalbased baits. Arthropod Management Tests 21, 403-404.

Faust, R.M., and Chandler, L.D. (1998) Future programs in areawide pest management. Foumal of Agricultural Entomology 15, 371-376.

Gerber, C.K. (2004) Testing the areawide pest management concept on western corn rootworm (Diabrotica virgifera virgifera LeConte) in northwestern Indiana and east central Illinois. PhD Dissertation, Purdue University, West Lafayette, Indiana.

Gray, M.E., Felsot, A.S., Steffey, K.L. and Levine, E. (1992) Planting time application of soil insecticides and western corn rootworm (Coleoptera: Chrysomelidae) emergence implications for long-term management programs. Fournal of Economic Entomology 85, 544-553.

Hein, G.L. and Tollefson, J.J. (1985) Use of Pherocon ${ }^{\circledR}$ AM trap as a scouting tool for predicting damage by corn rootworm (Coleoptera: Chrysomelidae) larvac. Journal of Economic Entomology 78, 200-203.

Hills, T.M. and Peters, D.C. (1971) A method of evaluating post-plant insecticide treatments for control of western corn rootworm larvae. Joumal of Economic Entomology 64, $764-765$.

Hoffmann, W.C. (1996) Applying areawide control to corn rootworms. Ag-Pilot International December 1996, pp. 64-65.

Hoffmann, W.C., Lingren, P.S., Coppedge, J.R. and Kirk, I.W. (1996a) Aerial application of SLAM $^{\mathbb{B}}$. Ag-Pilot International March 1996, 18-20.

Hoffmann, W.C., Lingren, P.S., Coppedge, J.R. and Kirk, I.W. (1996b) Corn rootworm control with a semiochemical-based insecticide. In: 1996 NAAA/ASAE Joint Technical Session, Paper No. AA96-007. ASAE, St Joseph, Michigan.

Hoffmann, W.C., Lingren, P.S., Coppedge, J.R. and Kirk, I.W. (1998) Application parameter effects on efficacy of a semiochemical-based insecticide. Applied Engineering in Agriculture 14, $459-463$. 
Hoffmann, W.C., Goppedge, J.R., Lingren, P.S. and Chandler, L.D. (2000) Impact of a semiochemical insecticide $\left(\mathrm{SLAM}^{\mathbb{B}}{ }^{\mathbb{B}}\right.$ ) on abundance of beneficial insects in corn. Southwestern Entomologist 25, 31-38.

Krysan, J.L., Foster, D.E., Branson, T.F., Ostlie, K.R. and Cranshaw, W.S. (1986) Two years before the hatch: rootworms adapt to crop rotation. Bulletin of the Entomological Society of America 32, 250-253.

Ladd, T.L., Stinner, B.R. and Krueger, H.H. (1983) Eugenol, a new attractant for the northern corn rootworm (Coleoptera: Chrysomelidae). Joumal of Economic Entomology 76 , 1049-1051.

Lampman, R.L. and Metcalf, R.L. (1987) Multicomponent kairomonal lures for southern and western corn rootworms (Coleoptera: Chrysomelidae) Diabrotica spp. Journal of Economic Entomology 80, 1137-1142.

Lampman, R.L., Metcalf, R.L. and Anderson, J.F. (1987) Semiochemical attractants of Diabrotica undecimpunctata howardi Barber, the southern corn rootworm and Diabrotica virgifera virgifera LeConte, the western corn rootworm (Coleoptera: Chrysomelidae). Journal of Chemical Ecology 13, 959-975,

Lance, D.R. (1988) Potential of 8-methyl-2-decyl propanoate and plant-derived volatiles for attracting corn rootworm beetles (Coleoptera: Chrysomelidae) to toxic baits. Joumal of Economic Entomology 81, 1359-1362.

Lance, D.R. and Elliott, N.C. (1991) Seasonal responses of corn rootworm beetles (Coleoptera: Chryomelidae) to non-pheromonal attractants. Journal of Entomological Science 26, 188-196.

Lance, D.R. and Sutter, G.R. (1990) Field-cage and laboratory evaluations of semiochemicalbased baits for managing western corn rootworm beetles (Coleoptera: Chrysomelidae). Joumal of Economic Entomology 83, 1085-1090.

Lance, D.R. and Sutter, G.R. (1991) Semiochemical-based toxic baits for Diabrotica virgifera virgifera (Coleoptera: Chrysomelidae): some effects of particle size, location, and attractant content. Joumal of Economic Entomology 84, 1861-1868.

Lance, D.R. and Sutter, G.R. (1992) Field tests of a semiochemical-based toxic bait for suppression of corn rootworm beetles (Coleoptera: Chrysomelidae). Joumal of Economic Entomology 85, 967-973.

Lingren, P.S. (1999) Management of Mexican corn rootworm, Diabrotica virgifera zeae Krysan and Smith (Coleoptera: Chrysomelidae), through areawide adult suppression and crop rotation. PhD Dissertation, Texas A\&M University, College Station, Texas.

Meinke, L.J. (1995) Adult Com Rootworm Management. University of Nebraska Bulletin MP63-C, Nebraska.

Meinke, L.J., Siegfried, B.D., Wright, R.J. and Chandler, L.D. (1998) Adult susceptibility of Nebraska western corn rootworm (Coleoptera: Chrysomelidae) populations to selected insecticides. Foumal of Economic Entomology 91, 594-600.

Metcalf, R.L. (1986a) Goevolutionary adaptions of rootworm bettles (Coleoptera: Chrysomelidae) to cucurbitacins. Foumal of Chemical Ecology 12, 1109-1124.

Metcalf, R.L. (1986b) Foreword. In: Krysan, J.L. and Miller, T.A. (eds) Methods for the Study of Pest Diabrotica. Springer-Verlag, New York, pp. vii-xv.

Metcalf, R.L. and Lampman, R.L. (1989) Estragole analogues as attractants for corn rootworm (Coleoptera: Chrysomelidae). Journal of Economic Entomology 82, 123-129.

Metcalf, R.L., Ferguson, J.E., Lampman, R. and Anderson, J.F. (1987) Dry cucurbitacincontaining baits for controlling diabroticite beetles (Coleoptera: Chrysomelidae). Journal of Economic Entomology 80, 870-875.

Metcalf, R.L., Rhodes, A.M., Metcalf, R.A., Ferguson, J., Metcalf, E.R. and Lu, P.Y. (1982) Cucurbitacin contents and diabroticite (Coleoptera: Chrysomelidae) feeding upon Cucurbita spp. Environmental Entomology 11, 931-937. 
Nowatzki, T.M., Tollefson, JJJ and Calvin, D.D. (2002) Development and validation of models for predicting the seasonal emergence of corn rootworm (Coleoptera: Chrysomelidae) beetles in Iowa. Environmental Entomology 31, 864-873.

Parimi, S., Meinke, L.J., Nowatzki, T.M., Chandler, L.D., French, B.W. and Siegfried, B.D. (2003) Toxicity of insecticide-bait mixtures to insecticide resistant and susceptible western corn rootworms (Coleoptera: Chrysomelidae). Crop Protection 22, 781-786.

Park, Y.L. and Tollefson, J.J. (2006) Development and economic evaluation of spatial sampling plans for corn rootworm Diabrotica spp. (Coleoptera, Chrysomelidae) adults. Joumal of Applied Entomology 130, 337-342.

Pingel, R.L., Behle, R.W., McGuire, M.R. and Sasha, B.S. (2001) Improvement of the residual activity of a cucurbitacin-based adult corn rootworm (Coleoptera: Chrysomelidae) insecticide. Foumal of Entomological Science 36, 416-425.

Quan, P.U. (1999) Corn rootworm control: economic evaluation of an areawide pest management approach. M.S. thesis, Purdue University, West Lafayette, Indiana.

Schroder, R.F.W., DeMilo, A.B., Lee, C.J. and Martin, P.A.W. (1998) Evaluation of water-soluble bait for corn rootworm (Coleoptera: Chrysomelidae) control. Joumal of Entomological Science $33,355-364$.

Schroder, R.F.W., Martin, P.A.W. and Athanas, M.M. (2001) Effect of phloxine B-cucurbitacin bait on diabroticite beetles (Coleoptera: Chrysomelidae). Journal of Economic Entomology 94, $892-897$.

Short, D.E. and Luedtke, R.J. (1970) Larval migration of the western corn rootworm. Fournal of Economic Entomology 63, 325-326.

Siegfried, B.D., Meinke, LJJ and Scharf, M.E. (1998) Resistance management concerns for areawide management programs. Fournal of Agricultural Entomology 15, 359-369.

Sutter, G.R. and Hesler, L.S. (1993) New biorational and environmentally safe technology for management of insect pests in maize production systems, In: Granholm, N.H. (ed.) Proceedings of Stress Symposia: Mechanisms, Responses, Management. College of Agricultural and Biological Sciences, South Dakota State University, Brookings, South Dakota, pp. 303-306.

Sutter, G.R. and Lance, D.R. (1991) New strategies for reducing insecticide use in the corn belt. In: Rice, B.J. (ed.) Sustainable Agriculture Research and Education in the Field-1990. Board of Agriculture National Research Council, National Academy Press, Washington, DC, pp. $231-249$.

Sutter, G.R., Branson, T.F., Fisher, J.R. and Elliott, N.C. (1991) Effects of insecticides on survival, development, fecundity, and sex ratio in controlled infestations of western corn rootworm (Coleoptera: Chrysomelidae). Joumal of Economic Entomology 84, 1905-1912.

Sutter, G.R., Lance, D.R., Meinke, L.J., Frana, J.E., Metcalf, R.L., Levine, E. and Gaggero, J.M. (1998) Managing Com Rootworms with a Granular Semiochemical-based Bait. USDA-ARS Publication \#143, Washington, DC, 40 pp.

Tollefson, JJ. (1998) Rootworm areawide management in Iowa. Journal of Agricultural Entomology $15,351-357$.

USDA (1993) Three Agency Release, Presidential Announcement Regarding IPM Adoption. Office of Communications, 23 June 1993, USDA, Washington, DC.

USDA (1994) USDA Announces National Plan to Increase use of Integrated Pest Management. Release Number 0943.94; and Backgrounder: USDA's IPM Initiative, Release Number 0942.94, Office of Communications, USDA, Washington, DC.

USDA-ARS/IDEA (2004) Controlling corn rootworm - the billion $\$ \$ \$$ insect; research provides new strategies. IDEA 22 July 2004, 4 pp.

Weissling, T.J. and Meinke, L.J. (1991a) Potential of starch encapsulated semiochemical-insecticide formulations for adult corn rootworm (Coleoptera: Chrysomelidae) control. Joumal of Economic Entomology 84, 601-609. 
Weissling, T.J. and Meinke, L.J. (1991b) Semiochemical-insecticide bait placement and vertical distribution of corn rootworm (Coleoptera: Chrysomelidae) adults: implications for management. Environmental Entomology 20,945-952.

Wilde, G.E., Whitworth, R.J., Shufran, R.A., Zhu, K.Y., Sloderbeck, P.E., Higgins, R.A. and Buschman, L.L. (1998) Rootworm areawide management project in Kansas. Joumal of Agricultural Entomology 15, 335-349.

Wright, R.J., Scharf, M.E., Meinke, L.J., Zhou, X., Siegfried, B.D. and Chandler, L.D. (2000) Larval susceptibility of an insecticide-resistant western corn rootworm (Coleoptera: Chrysomelidae) population to soil insecticides: laboratory bioassays, assays of detoxification enzymes, and field performance. Joumal of Economic Entomology 93, 7-13.

Zhu, K.Y., Wilde, G.E., Higgins, R.A., Sloderbeck, P.E., Buschman, L.L., Shufran, R.A., Whitworth, R.J., Starkey, S.R. and He, F. (2001) Evidence of evolving carbaryl resistance in western corn rootworm (Coleoptera: Chrysomelidae) in areawide-managed cornfields in north central Kansas. Journal of Economic Entomology 94, 929-934. 